\title{
AXIOLOGICAL ESTABLISHMENT OF A FUTURE SPECIALIST IN THE PROCESS OF PROFESSIONAL EDUCATION
}

\section{Pahuta M. V.}

\section{INTRODUCTION}

The question of the improvement of the efficiency of professional education is a key one, as in a general worldwide meaning as well as in the limits of Ukraine in particular. In the conditions of a market economy, the efficiency and competitiveness of any country in the world market is primarily determined by the ability to generate and implement new technologies, to produce a new high-tech product, which is not possible without the involvement of highly skilled workers. Therefore, the problem of the improvement of the quality of professional education is now one of the most urgent and discussed in the educational field of Ukraine.

This problem is extremely multifaceted and complex, since the effectiveness and quality of professional education are affected by many factors, ranging from the banal - logistical support of the educational process to the transformation of worldviews and values, both in the professional education system and in a society as a whole.

It is natural that depending upon the changes of the system of general public values, the change of the attitude of the society to assess of the effectiveness of professional education take place. This is especially true for large-scale socio-economic and socio-political transformations. This is the period that the country is experiencing today. Therefore, along with the revision and transformation of the old and formation of new social values in Ukraine there is a process of revision and change of educational values, including the professional education system ${ }^{1}$.

\footnotetext{
1 Товажнянский Л.Л., Романовський О.Г., Бондаренко В.В., Пономарьов О.С., Черваньова 3.О. Основи педагогіки вищої школи: Навчальний посібник. Харків: НТУ “ХПІ”, 2005. 600 с. (Рос. Мовою). Ст. 392.
} 
M. Kagan points out that values are extremely important component of human consciousness, in a concentrated form of which the content of the culture of the whole society is expressed ${ }^{2}$.

In this context, one of the highest priorities in professional education is axiological function of education, which should realize the values that today are not only important for a society and for the educational system, but also retain its relevance in the future.

For modern systems of professional education of Ukraine, the development of a new value system is typical, which provides individualization, humanization and democratization of the educational process, the use of learning technologies oriented on the activation of cognitive activity and the formation of social and personal important value orientations.

Value orientations are a relatively stable system of orientation of interests and needs of an individual, oriented on certain aspect of social values, which is formed in the process of social development of an individual, his participation in working life $^{3}$. Therefore, professional education can be considered as a means of becoming, development and transformation of value orientations of a future specialist.

In this regard, modern professional education can be and should be considered as a purposeful pedagogical process that ensures the formation and development of a holistic value attitude of an individual to the surrounding reality with the activation of motivational and evaluation processes, in which the acquisition and actualization of professionally relevant knowledge, abilities and skills is due to socially relevant professional and socio-cultural norms, general social, professional and personal value orientations ${ }^{4}$.

Consequently, it is professional education that usually acts as a means of formation, development and transformation of personal value

\footnotetext{
${ }^{2}$ Каган М.С. Человек как проблема современной философии. URL: https://http://www.anthropology.ru/ ru/text/kagan-ms/chelovek-kak-problema-sovremennoy-filosofii

3 Гончаренко С.У. Український педагогічний словник. К.: Либідь, 1997. 376 с. Ст. 357.

4 Елканова Т.М., Чеджемова Н.М., Сергеева Л.В. Аксиологические аспекты гуманитаризации современного профессионального образования. URL: https://www.readera.org/aksiologicheskie-aspektygumanitarizacii-sovremennogo-professionalnogo-140103092
} 
orientation of a future specialist but also a person to make value judgments as to the relevance of his professional or social activities to the actual professional and socio-cultural norms, general public, professional, and personal value orientations.

\section{Value orientations as a means of formation of the professional competence of a future specialist}

In our time, the competence approach is adopted for the characteristic of the compliance level of professional training of a specialist. Thus, $\mathrm{V}$. Kremen and a number of other scholars note that now, in modern society, the most important components in evaluating the quality of education are learning outcomes, which require the development of an integrated system of requirements to the results of education. Not so long ago, the results of training were viewed through the system of formed knowledge, skills and abilities, which is clearly not enough in the current conditions of society's development, and therefore they are now complemented by a set of competences that characterize a broader ability for professional self-realization of personality ${ }^{5}$.

Today, within the competence approach, such notions as competency and competence are used to evaluate the level of professional training of a specialist on the post-Soviet territories. In the post-Soviet psychologicalpedagogical theory and practice it is customary to separate these two terms.

N. Sidorchuk, summarizing the opinions of researchers on the specificity of the terms competency and competence, notes "... their integral character with the respect to "knowledge", "ability" and "skills" (is not contrary to them, but one that includes all their constructive meaning) as the notion of competence is characterized by knowledge, skills, abilities as well as personal qualities (initiative, commitment, goalsetting, responsibility, tolerance, etc.), social adaptation (ability to work in and outside the team), critical thinking as well as the experience in the chosen field. Only in the aggregate these components form behavioral

\footnotetext{
5 Біла книга національної освіти України / Т.Ф. Алексєєнко, В.М. Аніщенко, Г.О. Балл [та ін.]; за заг. ред. акад. В.Г. Кременя. К.: Інформаційні системи, 2010. 342 с. Ст. 244.
} 
models, and accordingly human competency in solving the tasks. On the whole, it can be argued that competency in Western culture is seen as a non-classical phenomenon, rooted in public educational practice and reflecting the existing balance of interests of society (to a lesser extent, of the state), educational institutions, employers, and consumers of services. The notions of competency and competence on the post-Soviet space are interpreted in the classic way as ideal entities that are subjects to explanation and comprehension. In such an interpretation, competency is defined by a complex characteristic of an individual, and competence as its constituent element" ${ }^{\prime 6}$.

I. Kozlovska in the dictionary-guide of a teacher-scientist indicates that competency is a range of powers of a person, issues on which he has some knowledge and experience. Accordingly, a person who has sufficient knowledge, is well-aware and skilled in any field of human activity will be competent ${ }^{7}$.

Analyzing the essence and structure of the notion of competency E. Samoilov includes four elements in competency: 1) personal values; 2) socio-political settings and restrictions; 3) basic training (knowledge, skills, abilities, experience of professional and creative activity); 4) competencies. The competencies are considered as complexes of heterogeneous personal psychological properties (cognitive, affective, volitional), which provide a person with the opportunity to realize complex types of practical-transformative actions and allow to achieve personalsignificant goals regardless of the nature of their origin and social structure in which a person lives and works ${ }^{8}$.

Thus, competency has a value component (personal, social and professional values); cognitive-operational component (basic (professional) knowledge, abilities, skills (KAS) and the methods of productive activity); activity-practical component (competence).

\footnotetext{
6 Сидорчук Н.Г. Порівняльний аналіз понять «компетенція» та «компетентність» як складних психолого-педагогічних феноменів. // Проблеми освіти: збірник наукових праць. Спецвипуск. ВінницяКиїв, 2015. С.78-81. Ст. 80.

${ }_{8}^{7}$ Козловська І.М. Словник-довідник педагога-науковця. Львів: Сполом, 2006. 74 с. Ст. 29.

8 Самойлов Е.А. Ценностные аспекты образования в информационном обществе. URL: https://www.cyberleninka.ru/article/v/tsennostnye-aspekty-obrazovaniya-v-informatsionnom-obschestve
} 
The first component indicates that the activity can be treated as effective when it conforms the human values and promotes harmonious development of the interconnected systems human - socium - nature. The second component of competency determines the importance for the modern world of the fundamental training of a person as the basis for the realization of his personal potential, for the effective accumulation of individual experience of moral-ethical and objectively reasonable transformation of the world. The need for competences as an important component of competency occurs in workers who are in a changing environment, where there are different alternatives of scenario development. In these conditions, competences are seen as a means of self-organization of an individual in the real conditions of their life. The key competencies that are necessary or important for most professions and are important for a society nowadays is the ability to communication and collaboration, leadership and innovation ${ }^{9}$.

In this case, an integral part of a person's overall competence is his or her professional competence. I. Kozlovska defines professional competence as a complete complex of knowledge, abilities, skills, psychological features (qualities), professional positions and acmeological invariants ${ }^{10}$.

In general, today in Ukrainian science, professional competency of a personality is treated not as a set of existing necessary professional knowledge, abilities, skills and professional experience as the ability of their actualization and creative transformation to perform their professional duties in modern dynamic conditions.

Thus, the use of competency approach to professional education in Ukraine includes not only the formation and development of specific, essential to the profession, competencies, but also the formation of living (personal and general societal) and professionally oriented value orientations of a future specialist.

In the process of development of the professional competency of a future specialist, fundamental vital values and personal motives and needs

\footnotetext{
9 Самойлов Е.А. Ценностные аспекты образования в информационном обществе. URL: https://www.cyberleninka.ru/article/v/tsennostnye-aspekty-obrazovaniya-v-informatsionnom-obschestve

${ }^{10}$ Козловська I.M. Словник-довідник педагога-науковця. Львів: Сполом, 2006. 74 с. Ст. 29.
} 
that reflect and influence the attitude of a person to the chosen career play an important role.

Therefore, considering the structure of professional competency, a number of scholars distinguish the following components in it: epistemological, praxeological and axiological. The epistemological component of professional competency defines the system of knowledge and skills that underlie in the basis of the solution of professionally oriented tasks using modern and new technologies. The praxeological component of professional competency determines the development of organizational, communication, analytical, informational, technological, search skills. The axiological component of professional competency is manifested in the value attitude of a person to the chosen profession, professional training and further professional activity, personal attitude to oneself in the profession and one's colleagues, attitude to professionally significant events, attitude to corporate culture and ethics, desire for a high level of acknowledgement of professionally important knowledge and skills, cognitive interest, achievement motivation ${ }^{11}$.

Accordingly, only the activity that do not contradict human and social values and promotes the harmonious development of a personality and society is considered effective in the terms of axiological aspects of professional education.

Thus, the basis of the formation of professional competency of a future specialist is value orientations, which on one hand, act as a process, in which a person creates his own personal value system by selection, transformation and subordination of existing general social and professional value system, bringing them to the state of personal-important value orientation, and on the other hand - act as a means of forming in an individual the ability to navigate in the existing socially important system of values, thus becoming the personal value of a future specialist ${ }^{12}$.

\footnotetext{
11 Кирьякова А.В., Бероева Е.А. Ценностные аспекты развития профессиональной компетентности специалиста в сестеме дополнительного профессионального образования. URL: https://www.cyberleninka.ru/ article/v/tsennostnye-aspekty-razvitiya-professionalnoy-kompetentnosti-spetsialista-v-sisteme-dopolnitelnogoprofessionalnogo-obrazovaniya

12 Дуранов М.Е. Управление проффесиональным образованием будушего специлиста в высшей школе (социокультурный аспект). Челябинск: ЧГАКИ, 2006. 337 с.
} 
Personal, social and professional values, as well as socio-political conditions and limitations are system forming factors of a person's professional competency.

The importance of personal values for the structure of a person's professional competency is due to the fact that they are extremely important for a person himself, his activity and determine the content of a person's activities, including professional ones. Individual values are extremely important and integral components of the structure of a human personality and is closely related to his needs.

Thus, the source of human activity is needs - the state of a living organism, human personality, social group or society as a whole, which expresses the need for something, dependence on the objective conditions of life and is the driving force of their activity, manifested in the activity aimed at the withdrawal of this dependency. It is distinguished biological needs that are inherent for living organisms and social needs that are of socio-historical in nature and predetermined by the development of material production ${ }^{13}$.

The needs are inherently of passive-active, subjectively-objective, socially-personal, subjective character. They are determined by passivity, because they are determined by certain conditions of human biosocial existence, namely deficiency in normal life. Each of us needs food, comfortable living conditions, cognition, etc.

And active character of needs is predetermined by the fact that they are active in overcoming such a deficit. That is, to meet their needs, people prepare or buy food, equip their homes, study, work.

Needs are also subjective as each person experiences lack of something depending on one's peculiarities. The meaning of any deficit is estimated by different people in different ways. They use a variety of methods and means of meeting the needs, which proves their subjective nature.

At the same time, the objective aspect of needs is determined by the fact that each of them is seen in lacking of certain objective objects or

\footnotetext{
${ }^{13}$ Гончаренко С.У. Український педагогічний словник. К.: Либідь, 1997. 376 с. Ст. 266.
} 
phenomena, appears in the objective situation of human life and has an objective value, is satisfied with the help of objective means. The content of the needs of an individual is largely determined by the level of cultural and historical development of the society in which he lives. At each stage, there are certain needs for human communities that are unique to the time at which they function. This determines the social nature of the needs. For example, with the rapid development of information processes and information systems, there was a need in computer technology, without which it is difficult to imagine the work of any institution today. At the same time, people solve this problem depending on the content of their own needs: some use a computer as a document printing tool, others as a efficient image processor, and others as a toy. Thus, needs function as a special form of reflection of the conditions of life of an individual ${ }^{14}$.

Human needs are multifaceted and diverse. Thus, along with higher (ideal) forms of behavior, which are caused by the influence of the learned socio-cultural elements learned in the process of learning, there are also natural forms of behavior that are caused by the natural needs of the body. Fluctuations in the normal rhythm of the biological life of the individual cause the uncertainty of human behavior as a complex system ${ }^{15}$.

Today, one of the most well-known and widespread systems of hierarchy of human needs is the hierarchy developed by A. Maslow ${ }^{16}$. The scholar selected seven hierarchical groups of human needs, which can be roughly in the shape of a pyramid: down in the bottom of the pyramid placed the needs that are important to all people without exception and they are related with the physiological inquiries of human needs (physiological needs) - in food, clothing, warm, shelter, etc; higher are based the needs in security; above, above them, are the needs for love, belonging to socium and demand of society; above, are personal needs for respect, success and authority; over them A. Maslow puts the needs for knowledge and investigation of the surrounding world; even higher are the

\footnotetext{
${ }_{15}^{14}$ Потребнісно-мотиваційна підсистема діяльності. URL: https://www.wikipage.com.ua/1 x8a3.html

Самойлов Е.А. Ценностные аспекты образования в информационном обществе. URL: https://www.cyberleninka.ru/article/v/tsennostnye-aspekty-obrazovaniya-v-informatsionnom-obschestve

${ }^{16}$ Маслоу А. Новые рубежи человеческой природы / Пер. с англ. М.: Смысл, 1999. 425 с.
} 
needs for beauty, harmony and aesthetics; and at the top of the pyramid there are the needs for self-actualization, development of one's abilities and personality as a hole, the realization of one's needs and ideas.

All needs A. Maslow placed accordingly to the degree of their importance, having explained such location by that each person can not feel the needs of a higher level, until the needs of lower levels are not satisfied. This is important to understand that it is not necessarily to satisfy the need in full demand, to move the individual to a higher level of sufficient or partial satisfaction of lower needs.

In particular, A. Maslow points out that in his opinion, a person can't live on bread only, that is, the need to satisfy only physiological needs. But if only there is enough bread (the physiological needs of a person are satisfied), from that time higher needs and motives appear. So gradually a person moves to the highest need - the need for self-development ${ }^{17}$. Thus, the needs, on the one hand, form value attitudes and orientations, and on the other - value orientations of a person correct and develop his motivational and need sphere.

The system of value orientations form component constituent of activity orientation of an individual and expresses the inner basis of its relationship to the surrounding reality. E. Podolska states that the value orientation is an important ideological target means that permeates through the human psyche to the needs and ideals can be both social and individual (personal) ${ }^{18}$.

The sociality of values lies in the fact that they are conditioned by the structure of social relations which are formed by the educational system and practice of the professional and public life. Instead, the individuality of values is linked to the individual characteristics of each individual, his or her life experience. Accordingly, axiological orientation are a complex, dynamic integrative system that synthesizes different levels of interaction between social and individual in a person and determines the general social

\footnotetext{
${ }_{17}^{17}$ Маслоу А. Новые рубежи человеческой природы / Пер. с англ. М.: Смысл, 1999. 425 с.

18 Подольская Е.А. Ценностная ориентация личности как предмет социально-философского иследования: автореф. дис. ... канд. филос. наук. М.: гос. ун-т им. М.В. Ломоносова, 1984. 23 с.
} 
orientation of an individual to value and practical activity in the professional environment ${ }^{19}$.

The development of professional competency from the perspective of axiological approach in professional education, significantly increases the efficiency of mastering a profession, ensuring a future specialist the formation and development of value attitude to future professional activity, increased personal position and internal motivation to continuous selfimprovement in the profession ${ }^{20}$.

The axiological component of professional competency is a kind of basis for the competent formation of a person's behavioral activity as an independent capacity for professional activity ${ }^{21}$. Therefore, professional values are an important factor in determining the professional behavior of a specialist and the interaction of all participants in the professional activity.

At the same time it is important to remember that today professional education is considered by a society not only as a process and result of assimilation of systematic professionally important knowledge, abilities and skills, without which the functioning of modern society is impossible, but also as a means of reproduction and development of the basic value socio-cultural components, formation of a socio-cultural personality of a future specialist.

N. Slusarenko and L. Lipschitz point out that a sociocultural personality can be considered as capable of self-affirmation for the purpose of self-realization and self-development, can act freely and successfully in different spheres of life, independently, creatively and unconventionally think, develop boldly his own behavioral strategies, to choose and be responsible for his actions and his own development, to construct positively his own life to the level of guaranteed achievement of success .

\footnotetext{
19 Елканова Т.М., Чеджемова Н.М., Сергеева Л.В. Аксиологические аспекты гуманитаризации современного профессионального образования. URL: https://www.readera.org/aksiologicheskie-aspektygumanitarizacii-sovremennogo-professionalnogo-140103092

${ }_{20}$ Кирьякова A.В., Бероева Е.А. Ценностные аспекты развития профессиональной компетентности специалиста в сестеме дополнительного профессионального образования. URL: https://www.cyberleninka.ru/ article/v/tsennostnye-aspekty-razvitiya-professionalnoy-kompetentnosti-spetsialista-v-sisteme-dopolnitelnogoprofessionalnogo-obrazovaniya

21 Хуторской А.В. Ключевые компетенции и образовательные стандарты : доклад на отделении философии образования и теории педагогики PAO 23 апреля 2002 года. URL: https://www.eidos.ru/ journal/2002/0423.htm
} 
Thus, a sociocultural personality is a person with a developed sociocultural competency $^{22}$.

Socio-cultural competency is formed on the basis and interrelation of relevant (subject, branch (general) and key) competencies of an individual. Thus the subject and branch competences of a future specialist are formed in him during the study of the subjects of fundamental and professionally oriented cycles $^{23}$.

Sociocultural competency is a system-forming factor of the professional culture of a future specialist, transforming it into a selfsufficient and open system capable of self-regulation and development. On the other hand, sociocultural competency is a subsystem of professional culture because it has the characteristics of a systematic component which components interact seamlessly with each other. Thus, we can state that socio-cultural competency is a set of relevant competences, an intricate, complex characteristic that reflects the integration of professionaltheoretical knowledge, value orientations, personal qualities and practical skills of a future specialists ${ }^{24}$.

\section{Motivational and value aspects of the culture of self-organization and professional adaptation of a future specialist}

The professional training of future professionals is a complex, multifaceted process. The quality of training, as well as its result - the level of competency, is influenced by many factors, including motivation and values of a future specialist's personality. As competences and values, as a planned result of professional training, require a complete combination of all professionally important knowledge, abilities, skills, value orientations with a personality of a future specialist. One of the main tasks of the

\footnotetext{
22 Слюсаренко Н.В., Липшиц Л.В. Компетентностный подход при формировании социокультурной личности будущего судоводителя. URL: https://www.https://cyberleninka.ru/article/v/kompetentnostnyypodhod-pri-formirovanii-sotsiokulturnoy-lichnosti-buduschego-sudovoditelya

${ }^{23}$ Микитенко Н.О. Технологія формування іншомовної комунікаційної компетентності майбутніх фахівців природничого профілю : монографія / за ред., д. пед. наук, проф., член-кор. НАПН України Г.В. Терещука. Тернопіль: ТНПУ, 2011. 411 с.

${ }^{24}$ Слюсаренко Н.В., Липшиц Л.В. Компетентностный подход при формировании социокультурной личности будущего судоводителя. URL: https://www.https://cyberleninka.ru/article/v/kompetentnostnyypodhod-pri-formirovanii-sotsiokulturnoy-lichnosti-buduschego-sudovoditelya
} 
student period of the development of professional competence of a future specialist is the formation of value attitude to the profession. The motivational value component is characterized by the following indicators: attitude to the profession as a value; understanding its importance to the society and one's own development; admiration for the profession and the pursuit of self-improvement in it, which can not be achieved without the ability of a future specialist to self-organization and further professional adaptation.

The notion of self-organization originated within synergetics and soon found its application in various fields of scientific knowledge. Selforganization, according to the synergistic approach, is a basic property of any living system that is its capacity for self-sufficiency, self-regulation and self-development via the use of its internal reserves and opportunities $^{25}$.

In psychological and pedagogical science, the notion "the culture of self-organization", although it does not have a single sustainable definition and from the point of view of professional education, is usually considered as the ability of a future specialist's personality to self-realization, which is manifested in his purposefulness, activity, validity of self-motivation and planning of his activity, independency, the speed of decision making and responsibility for them, the criticality and objectivity of self-evaluation of the results of one's activity, the sense of duty ${ }^{26}$.

The formation of the culture of self-organization of a personality is formed throughout the life of a person, but with different intensity in different periods of his ontogeny. One of the sensitive periods is the student's age, and it is the period of professional education of an individual. Thus, we can state that leading means of the creation of the culture of self-identity is professional education. Since the formation of the culture of self-organization is possible only after a personality reaches a

\footnotetext{
${ }^{25}$ Князькова О.Н. Мотивационно-ценностные аспекты культуры самоорганизации личности студента. URL: https://www.cyberleninka.ru/article/v/motivatsionno-tsennostnye-aspekty-kultury-samoorganizatsiilichnosti-studenta

${ }^{26}$ Фалеева Л.В. Организованость и самоорганизация как качество личности: сравнительный анализ понятий. Современные проблемы науки и образования. 2012. № 4. С. 266-274. Ст. 266.
} 
certain level of understanding of his life, understanding of a student, a future specialist, his role in the success of educational and further professional activity is a key factor in the functioning of all mechanisms of self-organization of the personality of a future specialist.

The culture of self-organization of a student's personality in the system of professional education is a complex value-systemic formation. In its structure, A. Knyazkova, identifies four components: cognitive, motivational and value, reflective and action-willed ${ }^{27}$.

The phenomenon of self-organization of a personality is most closely related to the value-motivational structure of a personality. The components of motivation-value orientation include motifs that represent a system of dominant motifs that can be viewed in the needs, interests, purpose, etc. and determine the behavior of man and the content of his activity as well as the system of value orientations that reflect the personality value of moral, social and cultural values. Ideals, beliefs, values and worldviews can be regarded as spiritual and value orientations of an individual. Thus, self-organization can be considered as a conscious set of motivation and value-based personality abilities of the personality of a future specialist, which are consistent with the individual characteristics of a subject and find their embodiment in the professional-cognitive values and techniques and the results of activity ${ }^{28}$.

The orientations in cognitive values reflect the results of future professional training in the professional education system. Most professionalcognitive values are the motives, means and results of cognitive activity.

Professional and educational values as one of the components of social values depend on the particular cultural, socio-cultural life and the formed motivational sphere of the personality of a future specialist.

A. Verbytskyi and N. Bakshayeva note that motivational sphere of a personality is a complex, dynamic, multi-level systemic unity of

\footnotetext{
27 Князькова О.Н. Мотивационно-ценностные аспекты культуры самоорганизации личности студента. URL: https://www.cyberleninka.ru/article/v/motivatsionno-tsennostnye-aspekty-kultury-samoorganizatsii-lichnostistudenta

28 Копеина Н.С. Самоорганизация в системе свойств индивидуальности. Личность в системе общественных отномений. Ч. 1. М.: АН СССР, 1983. С. 214-215. Ст. 214.
} 
interconnected components that are the set of socially important and fixed in ideal shape values ${ }^{29}$.

In the structure of the motivational sphere of the personality of a future specialist in the professional education system, there are two dominant groups of motives: motives for professional training and motives for professional activity. The motives for professional training determine the personal attitude of a future specialist to his professional education. Motives for professional activity (professional motives) cause personal attitude of a future specialist to further professional activity and are stable, conscious and taken to the realization of the desire to practice professional activity.

The source of these motives can be both internal needs of an individual and external influences. An inner motivated personally to mastering a profession is characterized by the fact that one's own educational purpose and tasks are meaningful and perceived by a future specialist as necessary and personally-meaningful, and all pedagogical actions and influences from external ones become personal-demanded ${ }^{30}$. Therefore, the presence of inner learning motives contributes to the achievement of high results both in educational activity in general and in the mastering of the chosen profession in particular.

Internal motives for professional training are usually manifested during independent educational and cognitive activity. They are focused on mastering new, professionally important competencies, including important professional knowledge, abilities, skills, and are provided by learning and cognitive and professionally-oriented activity, initiativeness and independency of a future specialist, the desire to form one's own professional competency. Their presence allows a future specialist to overcome independently all difficulties easily and quickly that arise in the course of his professional training.

\footnotetext{
${ }^{29}$ Бакшаева Н.А., Вербицкий А.А. Психология мотивации студентов : Учебное пособие». М.: Логос, 2006. 184 с. Ст. 25-34. URL: https://www.klex.ru/i81

${ }^{30}$ Современная психология мотивации / под ред. Д.А. Леонтьева. М.: Смысл, 2002. 343 с. Ст. 305-306. URL: https://www.https://www.klex.ru/85e
} 
On the other hand, the students who possess only external (that is, influenced by external factors) motivation for professional training, although are able to master the teaching material and solve typical tasks for their chosen profession, are almost unable to make professionally important and correct decisions on their own in difficult, atypical situations and determine and justify the overall direction of their actions ${ }^{31}$.

In all elements of the motivational sphere of a future specialist's personality, there are values and value orientations, which unlike the professionally important knowledge that a future specialist, in the course of professional training, receives in the prepared form, values and value orientations should be formed by himself. At the same time, as M. Kagan points out, the faster a future specialist manages to form his value orientations and personal-internal motives in the process of professional education, the faster and easier is the process of mastering and accumulation of professional knowledge, abilities and skills ${ }^{32}$, and hence the formation of professionally important competencies and accelerating the pace of the development of the culture of self-organization of the personality of a future specialist.

Along with the motivational and value component reflection and selfregulation plays a significant role in the formation of the culture of selforganization and further professional self-adaptation of a future specialist.

Reflection as a component of the culture of self-organization of the personality of a future specialist and his further professional adaptation implies an awareness of his acceptance and evaluation (as a personality, as a student - a future specialist, as a carrier of professionally important competences, etc.). This important aspect of social self-cognition is provided through self-examination and sharing other people's opinion. In psychology, reflection is called any reasoning of the person, aimed at the analysis of oneself (introspection) - one's own states, actions and past events. The depth of reflection, introspection depends on the level of

\footnotetext{
${ }^{31}$ Современная психология мотивации / под ред. Д.А. Леонтьева. М.: Смысл, 2002. 343 с. Ст. 303. URL: https://www.https://www.klex.ru/85e

${ }^{32}$ Каган М.С. Человеческая деятельность (Опыт системного анализа). М.: Политиздат, 1974. 328 с. Cт. 285. URL: https://www.twirpx.com/file/356786/
} 
human education, the development of moral feelings and the level of selfcontrol $^{33}$.

Reflection is extremely important for the effective training of future professionals in the professional education system, as it indicates the transition from full inclusion of self-consciousness in activity to the formation of a new attitude to the subject not only to the activity but also to himself in this activity. In the process of training of future specialists in the system of professional education, reflection involves not only understanding of a subject of himself and the nature of his activity, but also an idea how he and his activity is perceived by others. The development of the mechanisms of reflection stimulates introspection, the formation of will, personal maturity of a future specialist.

Along with the motivational-value component and reflection, the structure of the self-organization culture of a future specialist includes selfregulation.

The problem of self-regulation of educational activity of a future specialist plays an extremely important role in the system of professional education, the solution of which is directly related to the task of forming of a socially active personality, who achieves consistently high results in his / her future professional activity.

Self-regulation of educational activity is a system of self-organization of personal behavior, aimed at self-learning and self-education, and ensures the effectiveness of functioning of an individual in educational activity.

The system of self-regulation includes an internal arbitrary process of self-diagnosis of external and internal conditions, goal setting and evaluation of the possibilities and ways of achieving the goal, independence and initiative, self-control and self-assessment of the achieved result, self-correction.

\footnotetext{
33 Психологіс: енциклопедія практичної психології. URL: https://www.psychologis.com.ua/ refleksiya.htm
} 
The process of self-regulation of activity should always begin with self-diagnosis, go through the difficult path of internal work, and end with self-affirmation and self-correction.

A. Zobkov distinguishes the following indices of personal orientation, which are directly involved in the self-regulation of the educational activities of a future specialist: discipline, organization, responsibility, industriousness, independence and initiative, empathy, perseverance, confidence, cognitive activity, originality of thinking, reflection, flexible thinking ${ }^{34}$.

The development of axiological potential and the formation of the culture of self-organization of the personality of a future specialist implies qualitative changes in the value attitude to professional activity and oneself. Understanding by a future specialist the results of cognitive, selforganizing and communicative activity is a system-forming component of value self-determination, value orientations, which activates the process of cognition, creative activity, self-realization and determine the philosophical and ethical and professional choices ${ }^{35}$.

The substantive component of professional education is the formation of the personal culture of a future specialist. Therefore, creating the culture of self-organization of the personality of a future specialist directly related to the professional values and cultural identity, which forms the sociocultural environment in which a future specialist will adapt professionally, function and professionally grow to the level of a professional.

B. Bobrytska notes that mastering the new methods of activity, adjustment to new way of life, altered forms of organization of professional work of a specialist-beginner is realized within an extended period - professional adaptation. This is due to the difference between the characteristics of educational and educational-working activities in the institution of professional education from the conditions of professional

34 Зобков А.В. Саморегуляционные особенности студента - субьекта учебной деятельности. URL: https://www.https://cyberleninka.ru/article/v/samoregulyatsionnye-osobennosti-studenta-subektauchebnoy-deyatelnosti

35 Мелекесов Г.А. развитие аксиологического потенциала личности будущего учителя: автореф. дис. ... д-ра пед. наук. Оренбургский гос. ун-т. Оренбург, 2003. 36 c. URL: https://www.dissercat.com/ content/razvitie-aksiologicheskogo-potentsiala-lichnosti-budushchego-uchitelya/read 
work, changed communication situation, the need to work independently under increased stress, the need to assimilate a new social role in the period when the professional development of a personality and consolidate his values, positive motivation to further professional realization is strengthened ${ }^{36}$.

It should be noted that in the process of professional adaptation the reconstruction of the usual forms of behavior of an individual, ways of organizing his life and rest take place. Thus, the value-motivational aspect of adaptation requires from a former student, and now a young specialist, the reconstruction of the usual style of behavior, achieving greater flexibility in communication, acquiring individual and personal characteristics in accordance with the requirements of the team, which is achieved through a lot of effort with self-improvement, higher level of selfregulation $^{37}$.

\section{CONCLUSIONS}

The values of professional education play an extremely important role in the development of the personality of a future specialist. Personal value orientations formed in the course of professional training are a determining factor in the behavior of a future specialist and the relationships of all participants of professional activity. The development of professional competency from the point of view of the implementation of the axiological approach greatly increases the efficiency of mastering of professional activity, providing a future specialist the development of a value attitude to cognition, professional education and activity, activating personal position and intrinsic motivation for constant professional selfimprovement in the process of professional activity. The development of professional competency of a future specialist is expressed in the need of constant self-development, professional self-education and development of professional self-awareness.

\footnotetext{
36 Бобрицька В.І. Ціннісно-мотиваційні аспекти професійної адаптації фахівців 3 вищою освітою. URL: https://www.enpuir.npu.edu.ua/bitstream/123456789/14240/1/6_Bobrytska_Profes_adaptatsiya_2015.PDF

${ }^{37}$ Bobrytska V.I. Value measuring of psychophysical adaptation of a teacher-beginner // The Strategies of Modern Science Development: International scientific-practical conference. Science Book Publishing House, Yelm, WA, USA, 29-30 March 2013. P. 153-158. Ст. 155.
} 
Values aspects of professional competency in the system of professional education can be traced in such personal characteristics of future professionals as the ability to solve professional tasks of various complexity, mobility and tolerance, the formed system of personal and professional values (value orientations), the developed value-motivational component, unique individuality, creative origin, the formed culture of self-organization, reflection and self-organization.

We believe that the awareness of a future specialist of the axiological component of professional education, its importance for his professional development as a specialist may become a stable internal motive for successful educational and educational-professional activity.

\section{SUMMARY}

The results of theoretical research aimed at studying the axiological essence of professional education, its influence on the formation of professional competence of future specialists are reflected in the work. The structure and the role of motivation-value component on the formation of the culture of self-organization of an individual, his reflection and self-regulation are revealed.

\section{REFERENCES}

1. Товажнянский Л.Л., Романовський О.Г., Бондаренко В.В., Пономарьов О.С., Черваньова 3.О. Основи педагогіки вищої школи: Навчальний посібник. Харків: НТУ «ХПІ», 2005. 600 с. (Рос. Мовою).

2. Каган М.С. Человек как проблема современной философии. URL: https://http://www.anthropology.ru/ru/text/kagan-ms/chelovek-kakproblema-sovremennoy-filosofii

3. Гончаренко С.У. Український педагогічний словник. К.: Либідь, 1997. 376 с.

4. Елканова Т.М., Чеджемова Н.М., Сергеева Л.В. Аксиологические аспекты гуманитаризации современного профессионального образования. URL: https://www.readera.org/aksiologicheskie-aspektygumanitarizacii-sovremennogo-professionalnogo-140103092 
5. Біла книга національної освіти України / Т.Ф. Алексєєнко, В.М. Аніщенко, Г.О. Балл [та ін.]; за заг. ред. акад. В.Г. Кременя. К.: Інформаційні системи, 2010. 342 с.

6. Сидорчук Н.Г. Порівняльний аналіз понять «компетенція» та «компетентність» як складних психолого-педагогічних феноменів. // Проблеми освіти: збірник наукових праць. Спецвипуск. Вінниця-Київ, 2015. С. 78-81.

7. Козловська I.М. Словник-довідник педагога-науковця. Львів: Сполом, 2006. 74 с.

8. Самойлов Е.А. Ценностные аспекты образования в информационном обществе. URL: https://www.cyberleninka.ru/article/ v/tsennostnye-aspekty-obrazovaniya-v-informatsionnom-obschestve

9. Кирьякова А.В., Бероева Е.А. Ценностные аспекты развития профессиональной компетентности специалиста в сестеме дополнительного профессионального образования. URL: https://www.cyberleninka.ru/ article/v/tsennostnye-aspekty-razvitiya-professionalnoy-kompetentnostispetsialista-v-sisteme-dopolnitelnogo-professionalnogo-obrazovaniya

10. Дуранов М.Е. Управление проффесиональным образованием будущего специлиста в высшей школе (социокультурный аспект). Челябинск: ЧГАКИ, 2006. 337c.

11. Потребнісно-мотиваційна підсистема діяльності. URL: https://www.wikipage.com.ua/1x8a3.html

12. Маслоу А. Новые рубежи человеческой природы / Пер. с англ. М.: Смысл, 1999. 425 с.

13. Подольская Е.А. Ценностная ориентация личности как предмет социально-философского иследования: автореф. дис. ... канд. филос. наук. М.: гос. ун-т им. М.В. Ломоносова, 1984. 23 с.

14. Хуторской А.В. Ключевые компетенции и образовательные стандарты : доклад на отделении философии образования и теории педагогики PAO 23 апреля 2002года. URL: https://www.eidos.ru/ journal/2002/0423.htm

15. Слюсаренко Н.В., Липшиц Л.В. Компетентностный подход при формировании социокультурной личности будущего судоводи- 
теля. URL: https://www.https://cyberleninka.ru/article/v/kompetentnostnyypodhod-pri-formirovanii-sotsiokulturnoy-lichnosti-buduschego-sudovoditelya

16. Микитенко Н.О. Технологія формування іншомовної комунікаційної компетентності майбутніх фахівців природничого профілю : монографія / за ред., д. пед. наук, проф., член-кор. НАПН України Г.В. Терещука. Тернопіль: ТНПУ, 2011. 411 с.

17. Князькова О.Н. Мотивационно-ценностные аспекты культуры самоорганизации личности студента. URL: https://www.cyberleninka.ru/ article/v/motivatsionno-tsennostnye-aspekty-kultury-samoorganizatsiilichnosti-studenta

18. Фалеева Л.В. Организованость и самоорганизация как качество личности: сравнительный анализ понятий. Современные проблемы науки и образования. 2012. № 4. С. 266-274.

19. Копеина Н.С. Самоорганизация в системе свойств индивидуальности. Личность в системе общественных отношений. Ч.1. М.: АН ССCР, 1983. С. 214-215.

20. Бакшаева Н.А., Вербицкий А.А. Психология мотивации студентов : Учебное пособие». М.: Логос, 2006. 184 с. URL: https://www.klex.ru/i81

21. Современная психология мотивации / под ред. Д.А. Леонтьева. М.: Смысл, 2002. 343 c. URL: https:// www.klex.ru/85e

22. Каган М.С. Человеческая деятельность (Опыт системного анализа). М.: Политиздат, 1974. 328 c. URL: https://www.twirpx.com/ file/356786/

23. Психологіс: енциклопедія практичної психології. URL: https://www.psychologis.com.ua/refleksiya.htm

24. Зобков А.В. Саморегуляционные особенности студента субьекта учебной деятельности. URL: https://www.cyberleninka.ru/ article/v/samoregulyatsionnye-osobennosti-studenta-subekta-uchebnoydeyatelnosti

25. Мелекесов Г.А. развитие аксиологического потенциала личности будущего учителя: автореф. дис. ... д-ра пед. наук. Оренбургский гос. ун-т. Оренбург, 2003. 36 с. URL: 
https://www.dissercat.com/content/razvitie-aksiologicheskogo-potentsialalichnosti-budushchego-uchitelya/read

26. Бобрицька B.I. Ціннісно-мотиваційні аспекти професійної адаптації фахівців з вищою освітою. URL: https://www.enpuir.npu.edu.ua/ bitstream/123456789/14240/1/6_Bobrytska_Profes_adaptatsiya_2015.PDF

27. Bobrytska V.I. Value measuring of psychophysical adaptation of a teacher-beginner // The Strategies of Modern Science Development: International scientific-practical conference. Science Book Publishing House, Yelm, WA, USA, 29-30 March 2013. P. 153-158.

\section{Information about the author:}

Pahuta M. V.

Candidate of Pedagogic Sciences, Associate Professor,

Doctoral Student at the General Pedagogy and Preschool Education Department,

Drohobych Ivan Franko State Pedagogical University 24, Ivan Franko str., Drohobych, 82100, Ukraine 